Vol. 1 No. 4 Oktober 2021 e-ISSN : 2774-6283 | p-ISSN : 2775-0019

\title{
IMPLEMENTASI MULTIMEDIA BASED LEARNING \\ VIA SELF VIDEO RECORDING (SVR) UNTUK MENINGKATKAN KEMAUAN SISWA SMKN 2 BANDAR LAMPUNG DALAM BERKOMUNIKASI
}

\author{
RINNA SLAMET \\ SMK Negeri 2 Bandar Lampung, Provinsi Lampung \\ e-mail: missrinsla@gmail com
}

\begin{abstract}
ABSTRAK
Salah satu kunci keberhasilan pembelajaran Bahasa Inggris adalah tumbuhnya kemauan siswa untuk aktif berbicara guna mengimplementasikan teori yang telah mereka dapatkan. Sebagaimana lazimnya sebuah keahlian, jika tanpa dibiasakan pasti akan terasa berat dan sulit. Begitulah yang terjadi pada siswa kelas XII DPIB 2, dimana rata-rata mereka enggan berbicara, baik bertanya ataupun menjawab pertanyaan guru. Mereka pasif, dan lebih banyak diam. Ada banyak hal yang melatarbelakangi ketakutan mereka seperti takut salah, takut malu, dan tidak punya kepercayaan diri karena minimnya kosa kata dan latihan bicara. Pada penelitian ini bertujuan untuk meningkatkan kemauan siswa dengan implementasi pembelajaran menggunakan Self Video Recording (SVR) dapat meningkatkan kemauan siswa dalam berbicara dan aspek apakah yang paling banyak dipengaruhi oleh SVR. Penelitian ini dilaksanakan di SMK Negeri 2 Bandar Lampung selama dua bulan, yaitu Januari dan Februari 2019 pada siswa kelas XI jurusan Desain Pemodelan Informasi dan Bangunan (DPIB). Penulis menggunakan desain one-group pretest-posttest, dimana para siswa disajikan pertanyaanpertanyaan pada sebuah kusioner tentang kemauan berkomunikasi (willingness to communicate). Kuesionaer tersebut berisi 25 pertanyaan yang mampu mengungkap pada situasi seperti apa mereka mau berkomunikasi pada kelas Bahasa Inggris. Untuk mencapai tujuan, penulis melakukan $1 \mathrm{x}$ pretest, $3 \mathrm{x}$ perlakuan, dan $1 \mathrm{x}$ posttest. Setelah membandingkan hasil pretest dan posttest, maka hipotesa tes yang menyatakan bahwa implementasi pembelajaran menggunakan self video recording dapat menunjukkan perbedaan yang signifikan sebelum dan sesudah pelaksanaan pembelajaran selama $\mathrm{T}$-value $>\mathrm{T}$-table dengan tingkat signifikan dibawah 0,05 .
\end{abstract}

Kata kunci: Self Video Recording (SVR), kemauan berkomunikasi, one group pretest-posttest design.

\section{ABSTRACT}

One of the keys to the success of learning English is the growth of students' willingness to actively speak in order to implement the theory they have learned. As is usually a skill, if you don't get used to it, it will definitely feel heavy and difficult. That's what happened to class XII DPIB 2 students, where on average they were reluctant to speak, either asking or answering the teacher's questions. They are passive, and mostly silent. There are many things behind their fear such as fear of being wrong, fear of shame, and lack of confidence due to lack of vocabulary and speaking practice. This study aims to increase students' willingness to implement learning using Self Video Recording (SVR) to increase students' willingness to speak and what aspects are most influenced by SVR. This research was conducted at SMK Negeri 2 Bandar Lampung for two months, namely January and February 2019 for class XI students majoring in Information and Building Modeling Design (DPIB). The author uses a one-group pretestposttest design, where students are presented with questions on a questionnaire about willingness to communicate. The questionnaire contains 25 questions that are able to reveal in what situations they want to communicate in English class. To achieve the goal, the writer did $1 \mathrm{x}$ pretest, $3 \mathrm{x}$ treatment, and $1 \mathrm{x}$ posttest. After comparing the results of the pretest and posttest, the test hypothesis which states that the implementation of learning using self video recording can show a significant difference before and after the implementation of learning as long as the T-value > T-table with a significant level below 0.05 . 
Keywords: Self Video Recording (SVR), willingness to communicate, one group pretestposttest design.

\section{PENDAHULUAN}

Mengajar bukan pekerjaan yang mudah. Dibutuhkan bukan hanya kecerdasan intelektual (IQ/Intelligence Quotient) tapi juga kecerdasan emosional (EQ/Emotional Quotient) dan inter/intra-personal. Kecerdasan intelektual mengukur kemampuan seorang guru secara akademik; kecerdasan emosional mengukur kemampuan guru dalam menyadari dan mengelola emosi diri sendiri, memiliki kepekaan terhadap emosi orang lain, mampu merespon dan bernegosiasi dengan orang lain secara emosional, serta dapat menggunakan emosi sebagai alat untuk memotivasi diri; kecerdasan interpersonal menunjukkan kemampuan seseorang guru untuk dapat memahami dan berinteraksi dengan orang lain sehingga mudah bersosialisasi dengan lingkungan di sekelilingnya (Gardner;1993); dan kecerdasan intrapersonal mengukur kemampuan diri sendiri dengan teliti dan lalu menggunakan kemampuannya sebagai alat untuk menempuh kehidupan secara efektif." (Goleman, 2002 : 52). Dengan memiliki kecerdasan ini, seorang guru diharapkan mampu mengidentifikasi kemampuan diri sendiri dalam kerkreativitas mengajar, dan lalu mengapresiasikannya kedalam bentuk kreasi pembelajaran yang bermanfaat untuk meningkatakan bukan hanya kreativitas guru tersebut tetapi juga meningkatkan motivasi siswa dalam proses pembelajaran.

Pada tugasnya sebagai pendidik, bukan tidak mungkin seorang guru tidak menemui kendala. Akan muncul berbagai permasalahan baik dari para siswa maupun diri sendiri. Namun, tidak akan ada penyakit jika tidak ada obatnya. Segala permasalahan yang terjadi pada proses pembelajaran pasti ada pemecahannya asal kita mau. Maka, motivasi seorang guru amat berperan penting untuk berhasilnya sebuah proses pembelajaran.

Pada mata pelajaran Bahasa Inggris, ada empat keahlian (skill) yang harus dikuasai dan menjadi dasar penilaian meliputi: listening skill (keahlian mendengar), speaking skill (keahlian berbicara), writing skill (keahlian menulis), dan reading skill (keahlian membaca). Dari keempat keahlian tersebut, keahlian berbicara (speaking) merupakan keahlian yang paling sulit dilakukan . Pada saat diberi kesempatan untuk mengungkapkan pendapat, mereka terlihat gugup, atau hanya diam karena tidak mampu mengungkapkan idenya. Ada beberapa alasan mengapa siswa sulit berkomunikasi menggunakan bahasa Inggris. Pertama adalah karena siswa tidak menguasai berbagai aspek dalam good speaking meliputi aspek pronunciation (pengucapan), diction (pilihan kata), grammar (tata bahasa), vocabulary (kosa kata), dan fluency (kelancaran). Semua aspek tersebut akan dengan mudah diidentifikasi oleh lawan bicara apabila terdapat kesalahan. Aspek kedua adalah karena siswa kurang familiar dengan tema dalam pembelajaran, dan yang terpenting adalah karena kurangnya motivasi siswa dalam belajar.

Pada praktiknya, berdasarkan observasi yang penulis lakukan selama mengajar di kelas X SMKN 2 Bandar Lampung, rata-rata siswa banyak menemui kendala pada saat mereka diberi kesempatan untuk menjawab pertanyaan apalagi untuk mengemukakan pertanyaan. Pada saat diberi pertanyaan simple, terkait identitas diri, mereka kesulitan untuk menjawab dengan cara yang tepat. Beberapa yang bisa menjawab, jarang sekali yang mampu memberikan jawaban komplit dan benar secara grammar. Rata-rata mereka bisa benar menjawab jika pertanyaannya bertipe yes-no questions (Contoh: “Do you like football?", “Are you a student?”). Berdasarkan pengamatan penulis, mereka rata-rata hanya mampu menjawab dengan ucapan "yes" atau "no" saja. Padahal, jika dijawab secara lengkap harusnya dijawab dengan "yes, I do" dan "yes, I am". Agak sulit rupanya bagi mereka membedakan mana yes yang harus diakhiri I do dan mana yang diakhiri I am. Terlebih jika jenis pertanyaan yang diberikan masuk kategori WH-Questions, seperti: "Where were you born?" atau "Why do you study here?". Kebanyakan mereka hanya saling pandang, tersenyum, atau bertanya balik, "Maksudnya gimana Mam?" Dari pengalaman yang didapatkan di dalam kelas ini, penulis kemudian menyimpulkan bahwa sebenarnya ada yang kurang dari cara belajar siswa. Apa itu? Latihan. Disini siswa kurang bisa memanfaatkan 
media, waktu dan kesempatan serta kurang mendapatkan motivasi untuk sering melatih kemampuan berbicaranya. Jika mau, ada banyak media sosial seperti channel youtube, tiktok, dan link google sebagai tempat bertanya. Ada pula banyak waktu luang dan kesempatan yang bisa mereka manfaatkan sebaik mungkin untuk menimba ilmu. Akan tetapi, motivasi yang kurang dari diri mereka menjadi factor penting yang berpengaruh terhadap rendahnya minat mereka dalam berlatih.

Dengan menggabungkan empat jenis kecerdasan (intelektual, emosional, interpersonal dan intrapersonal), seorang guru diharapkan mampu menganalisa penyebab rendahnya motivasi siswa dalam interaksi belajar, dalam mengungkapkan pendapat pada saat interaksi kelas, dan lalu sesuai dengan kebutuhan siswa (students' need) berusaha menemukan metode baru yang dapat merangsang kreativitas siswa dan membangun kemauan mereka untuk berbicara dalam Bahasa Inggris. Menarik saja belum cukup. Guru harus mampu mengaitkan metode yang ia gunakan dengan silabus atau kurikulum terbaru (kurikulum 2013/K-13) dan selaras dengan perkembangan teknologi masa kini, yaitu pembelajaran dengan multimedia.

Pembelajaran dengan multimedia merupakan salah satu ciri khas pembelajaran era globalisasi, yang sesuai dengan tuntutan jaman. Dengan mempertimbangkan prinsip dasar kurikulum 2013 dimana pembelajaran sudah tidak lagi berasas pada Teacher-Centered Learning melainkan pada Students-Centered Learning, pembelajaran dengan multimedia diharapkan dapat memotivasi para siswa untuk meningkatkan kreativitasnya pada proses pembelajaran, sehingga hasilnya akan lebih nyata. Diungkapkan oleh Gilakjani (2012) bahwa : "If the students are not interested in the material presented, they will not learn it". Jika siswa tidak tertarik pada materi yang sedang diberikan, mereka akan enggan mempelajarinya. Dengan menggunakan media teknologi khususnya multimedia, dipercaya dapat meningkatkan kemauan atau motivasi anak didik dalam belajar karena multimedia dapat membuat pembelajaran menjadi lebih menarik dan tidak membosankan. Hal ini didukung oleh pendapat Pun (2013) yang menyatakan bahwa saat ini pembelajaran Bahasa Inggris secara tradisional kurang efektif, sehingga kita butuh teknologi multimedia dengan audio visual dan animasi yang dapat memotivasi siswa untuk belajar lebih cepat dan efektif. Dari pernyataan tersebut, jelaslah bahwa multimedia-based learning akan amat memberikan kontribusi terhadap hasil belajar anak karena pembelajaran ini amat efektif dalam merangsang kreativitas anak didik untuk ikut berinteraksi dalam pembelajaran.

Ada berbagai macam media yang dapat digunakan guru dalam proses pembelajaran, salah satunya adalah pembelajaran dengan menggunakan video. Yang selama ini berlangsung, guru menggunakan media video yang di dapatkan dari sumber tertentu (dari teman sejawat atau pusat pelatihan), membeli di toko buku terkemuka, atau download langsung dari internet. Pada kesempatan ini, penulis menawarkan penggunaan SVR (Self-Video Recording), yaitu sebuah rekaman video hasil karya siswa untuk dijadikan media pembelajaran didalam kelas. Siswa dapat bekerja secara kelompok atau individu sesuai dengan jenis tugasnya. Tema yang ditentukan oleh guru diambil dari materi pembelajaran sesuai dengan silabus dan pembelajarannya diaplikasikan dengan menggunakan pendekatan terbaru yang dicanangkan pada kurikulum 2013 yaitu pendekatan Saintifik (scientific approach ). Proses pembelajaran yang mengacu pada pendekatan saintifik menurut Kementerian Pendidikan dan Kebudayaan (2016) meliputi lima langkah, yaitu: mengamati, menanya, mengumpulkan data, mengasosiasi, dan mengkomunikasikan, sebagaimana terurai dibawah ini:

1. Mengamati, yaitu kegiatan siswa mengidentifikasi melalui indera penglihat (membaca, menyimak), pembau, pendengar, pengecap dan peraba pada waktu mengamati suatu objek dengan ataupun tanpa alat bantu.

2. Menanya, yaitu kegiatan siswa mengungkapkan apa yang ingin diketahuinya baik yang berkenaan dengan suatu objek, peristiwa, suatu proses tertentu.

3. Mengumpulkan data, yaitu kegiatan siswa mencari informasi sebagai bahan untuk dianalisis dan disimpulkan.

4. Mengasosiasi, yaitu kegiatan siswa mengolah data dalam bentuk serangkaian 
aktivitas fisik dan pikiran dengan bantuan peralatan tertentu.

5. Mengkomunikasikan, yaitu kegiatan siswa mendeskripsikan dan menyampaikan hasil temuannya dari kegiatan mengamati, menanya, mengumpulkan dan mengolah data, serta mengasosiasi yang ditujukan kepada orang lain baik secara lisan maupun tulisan.

Penggunaan media pembelajaran berupa Self-Video Recording ini diharapkan mampu menumbuhkan kemauan siswa untuk berinteraksi dan mengemukanan pendapat dalam diskusi kelas pada pelajaran Bahasa Inggris. Video yang dibuat oleh rekan sekelas akan lebih menarik dilihat karena para siswa sudah mengenal pemeran dalam video tersebut.

Untuk mengaplikasikan pembelajaran menggunakan media Self-Video Recording (SVR) ini, ada lima model pembelajaran yang dapat di adopsi dari kurikulum terbaru kita, (K13), meliputi metode pengajar Inquiry Based Learning, Discovery Based Learning, Project Based Learning, dan Problem Based Learning. Dari keempat model pembelajaran yang ditawarkan oleh kurikulum terbaru, penulis memilih Discovery Learning sebagai metode dalam mengajarkan SVR kepada siswa dengan harapan siswa termotivasi untuk berinteraksi menggunakan Bahasa Inggris baik didalam maupun diluar lingkungan sekolah.

"Discovery learning is a method that encourages students to arrive at a conclusion based upon their own activities and observations. Inclusion of activities based on discovery learning in science teaching in Turkey is important for meaningful and lifelong learning. The activities in science teaching raise the curiosity of students and drive them to inquire their priorities and perceive the natural phenomena from different aspects. Such activities help to correct the conceptual errors of students". (Kaptan \& Korkmaz, 2000). Dari kutipan diatas, dapat dijelaskan bahwa Discovery Learning adalah sebuah metode yang mengajak siswa untuk menemukan sebuah kesimpulan berdasarkan pengalaman belajar yang mereka ciptakan sendiri. Pengalaman belajar yang mereka dapatkan selama proses pembelajara, sangat berperan penting dan memberi pembelajaran selama hidup mereka. Dalam proses tersebut juga tumbuh rasa penasaran yang menggiring mereka untuk terus mencari tahu tentang berbagai aspek penyebab kegagalan dan penunjang keberhasilan proses pembelajaran dari berbagai sudut pandang yang berbeda.

Menurut pendapat Rohani (2004:24) Discovery Learning adalah suatu pandangan bahwa peserta didik sebagai subyek di samping sebagai obyek pembelajaran. Mereka memiliki kemampuan dasar untuk berkembang secara optimal sesuai dengan kemampuan yang mereka miliki. Proses pembelajaran harus dipandang sebagai suatu stimulus atau rangsangan yang dapat menantang peserta didik untuk merasa terlibat atau berpartisipasi dalam aktivitas pembelajaran. Peranan guru hanyalah sebagai fasilitator dan pembimbing atau pemimpin pengajaran yang demokratis, sehingga diharapkan peserta didik lebih banyak melakukan kegiatan sendiri atau dalam bentuk kelompok memecahkan masalah atas bimbingan guru.

Menurut beberapa pendapat diatas, penulis berpendapat bahwa discovery learning yang diterapkan pada pembelajaran Bahasa Inggris menggunakan Self Video Recording akan sangat menginspirasi dan merefleksikan secara nyata bagaimana para siswa bekerja secara mandiri dan terkoordinir bersama kelompoknya sehingga mampu menjadi mandiri dan mengambil manfaat dari proses yang mereka jalani tanpa bantuan guru karena disini guru hanya sebagai pembimbing atau fasilitator dengan memberikan kesempatan kepada siswa untuk beajar secara aktif agar dapat berkembang secara optimal sesuai dengan kemampuan mereka.

Pada penelitian ini, ada dua pertanyaan yang akan dicari jawabannya: 1) apakah ada perbedaan yang signifikan pada kemauan siswa untuk berkomunikasi sebelum dan setelah implementasi pembelajaran melalui SVR, dan 2) aspek apa yang paling banyak dipengaruhi oleh teknik pembelajaran menggunakan SVR.

\section{METODE PENELITIAN}

Penelitian dilaksanakan di SMK Negeri 2 Bandar Lampung selama dua bulan, yaitu Januari dan Februari 2019 pada siswa kelas XI jurusan Desain Pemodelan Informasi dan 
Bangunan (DPIB). Terdapat tiga puluh empat siswa sebagai responden dalam penelitian ini dimana 28 adalah laki-laki dan sisanya adalah perempuan. Berdasarkan tujuan yang ingin penulis capai, yaitu mencari tahu apakah penggunaan Self Video Recording dapat menunjukkan perbedaan yang signifikan setelah implementasinya dalam pembelajaran sehingga mampu meningkatkan kemauan siswa untuk berbicara.

Dalam penelitian ini, penulis menggunakan desain one-group pretest-posttest, dimana para siswa disajikan pertanyaan-pertanyaan pada sebuah kusioner tentang kemauan berkomunikasi (willingness to communicate). Kuesionaer tersebut berisi 25 pertanyaan yang mampu mengungkap pada situasi seperti apa mereka mau berkomunikasi pada kelas Bahasa Inggris. Sumber kuesioner tersebut didapatkan dari mengadaptasi kuesioner penelitian oleh Pattapong (2010). Untuk penyesuaian dengan judul dan tujuan penelitian, penulis hanya mengambil 17 pertanyaan terkait situasi berbicara/berkomunikasi dari jumlah total 25 pertanyaan yang Pattapong miliki. Skala penilaian yang digunakan pada penelitian ini adalah 1 (sangat tidak bersedia), 2 (mungkin tidak bersedia), 3 (mungkin bersedia), 4 (bersedia), 5 (sangat bersedia).

Setelah dilakukan pretest, siswa mendapatkan tiga kali pembelajaran menggunakan Self-Video Recording. Lalu, setelah selesai, dilakukan posttest untuk mengukur sejauh mana kemauan siswa untuk berkomunikasi setelah tiga kali proses pembelajaran menggunakan SelfVideo Recorning. Penulis juga mencari tahu aspek apa yang paling mempengaruhi kemauan siswa saat memulai berbicara, sehingga dapat meningkatkan kemauan mereka dalam berkomunikasi. Desain penelitian yang digunakan adalah: T1 (X1 X2 X3) T2

Pada prosedur penelitian, langkah-langkah yang penulis lakukan secara berturut-turut adalah: melakukan observasi kelas, menentukan masalah dan subjek penelitian, menentukan teknik pengumpulan data, menentukan jadwal penelitian, melaksanakan pretest, embagi siswa kedalam beberapa grup, menyusun dialog, melaksanakan pembelajaran (treatment), melaksanakan posttest, membagi kuesioner tentang persepsi siswa, melakukan interview, menganalisis data, dan membuat laporan penelitian.

\section{HASIL DAN PEMBAHASAN}

Hasil

Penelitian ini dilaksanakan dalam lima kali pertemuan. Pada pertemuan pertama (5 Maret 2019), penulis memberikan pretest. Lalu, pada pertemuan selanjutnya (12 Maret 2019), penulis memulai perlakuan 1, yaitu mengajar menggunakan self video recording. Perlakuan ini lalu dilanjutkan hingga genap tiga kali yaitu perlakuan 2 pada tanggal 19 dan 26 Maret 2019. Sgera setelah selesai perlakuan-3, penulis langsung memberikan posttest. Pada pertemuan selanjutnya (2 April 2019), penulis membagikan kuesioer tentang persepsi siswa terhadap pembelajaran menggunakan self video recording (SVR).

Untuk menjawab pertanyaan penelitian yang pertama, maka dilakukan pretest dengan tujuan untuk mengetahui seberapa jauh kemauan siswa untuk berkomunikasi sebelum perlakuan pembelajaran menggunakan self video recirding (SVR). Aktivitas ini dilakukan pada hari Selasa, tanggal 5 Maret 2019. Membutuhkan kurang lebih 30 menit untuk menjawab pertanyaan pretest. Hasil dari pretest tersebut adalah sebagaimana yang tertera pada data dibawah ini:

Table 1. Nilai rata-rata pretest Statistik sampel berpasangan pada pretest

\begin{tabular}{|r|r|r|r|r|}
\hline & Mean & \multicolumn{1}{|c|}{ N } & Std. Deviation & Std. Error Mean \\
\hline PreTest & $\mathbf{3 , 0 7 7 6}$ & $\mathbf{3 4}$ & $\mathbf{4 4 3 8 9}$ & $\mathbf{0 7 6 1 3}$ \\
& & & & \\
\hline
\end{tabular}

Berdasarkan table diatas, dapat kita lihat bahwa nilai rata-rata pretest tentang kemauan siswa untuk berkomunikasi adalah 3,0776. 




Gambar 1. Hasil pretest kemauan berkomunikasi siswa

Setelah melakukan pretest, dilaksanakan tiga kali perlakuan pembelajaran menggunakan self video recording. Segera setelah perlakuan ketiga, dilakukan posttest untuk mengetahui efek dari tiga kali perlakuan pembelajaran. Posttest yang dilaksanakan pada tanggal 26 Maret 2019 menghasilkan data sebagaimana yang tampak pada tabel berikut:

Tabel 2. Nilai rata-rata posttest Statistik sampel berpasangan pada posttest

\begin{tabular}{|c|c|c|c|c|}
\hline & Mean & N & Std. Deviation & Std. Error Mean \\
\hline & & & & \\
PostTest & $\mathbf{4 , 1 0 8 2}$ & $\mathbf{3 4}$ & $\mathbf{1 2 6 6 9}$ & $\mathbf{0 2 1 7 3}$ \\
\hline
\end{tabular}

Berdasarkan table diatas, dapat kita lihat bahwa nilai rata-rata kemauan siswa untuk berkomunikasi setelah perlakuan pembelajaran menggunakan self video recording adalah 4,1082 .

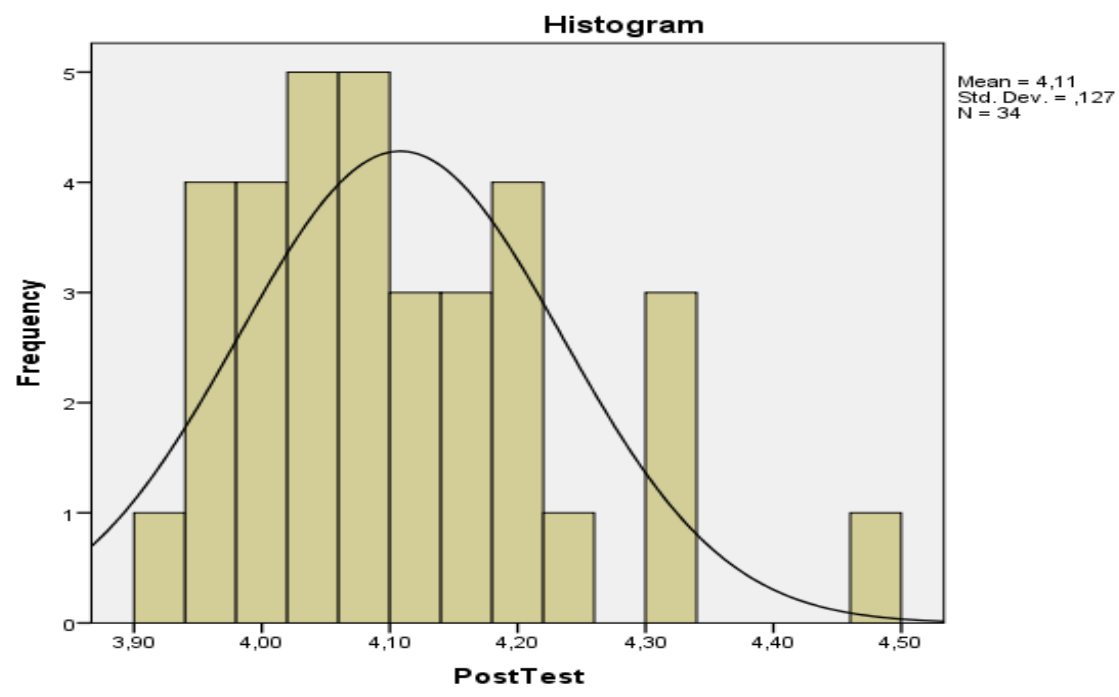

Gambar 2. Hasil posttest kemauan berkomunikasi siswa

Dengan membandingkan hasil pretest dan posttest, maka hipotesa tes yang menyatakan bahwa implementasi pembelajaran menggunakan self video recording dapat menunjukkan perbedaan yang signifikan sebelum dan sesudah pelaksanaan pembelajaran selama T-value > T-table dengan tingkat signifikan dibawah 0,05 . 
Nilai hasil pretest dan posttest siswa dari kuesioner yang diberikan, dihitung dengan menggunakan SPSS versi 23. Dengan menggunakan paired sample T-test, didapatkan perbedaan yang signifikan antara hasil pretest dan posttest karena nilai variable dari sig. (2-tail) adalah .000 sebagaimana yang tampak pada table dibawah ini. Hipotesa Ho yang menyatakan bahwa tidak ada perbedaan yang signifikan sebelum dan sesudah perlakuan ditolak. Pada table tersebut tampak bahwa hasil nilai rata-rata posttest lebih tinggi daripada pretest (T-value 14,642 $>$ T-tabel 2,0345).

Tabel 3. Hasil nilai prestest dan posttest kemauan berkomunikasi Tes sampel berpasangan

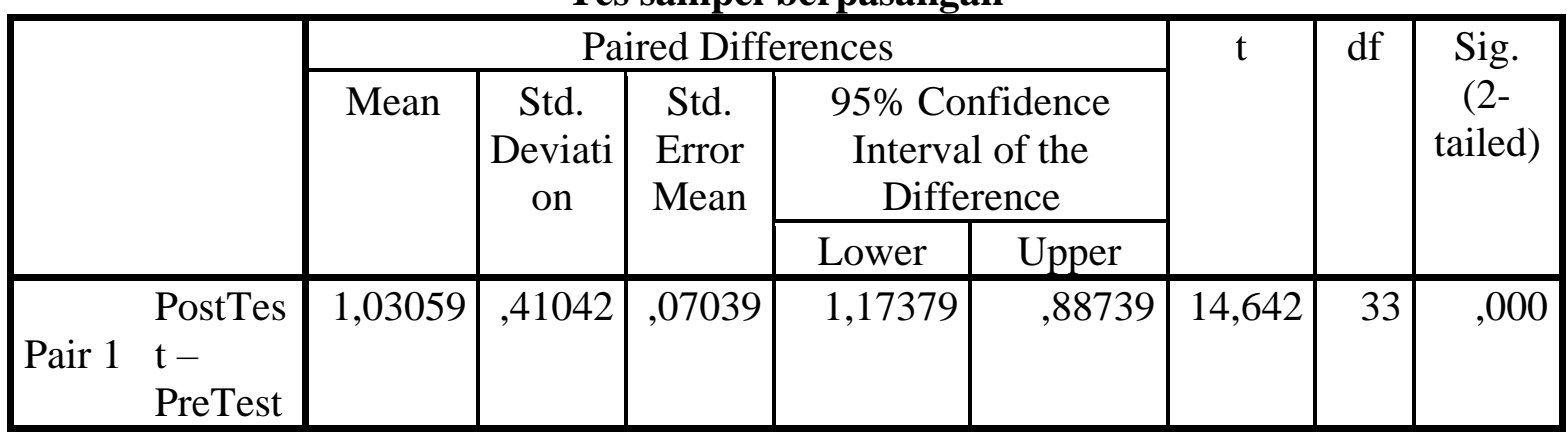

Pada penelitian sebelumnya oleh Chotipaktanasook (2014) yang berjudul Enhancing Learners' Willingness to Communicate in English with Social Media juga meneliti tentang penggunaan media social sebagai alat bantu tes Bahasa via computer guna mencari tahu efeknya terhadap kemauan berbicara. Setelah dianalisa, didapatkan hasilnya bahwa kemauan siswa untuk berinteraksi dan berbicara lpada kelas yang via media social lebih tinggi daripada interaksi mereka dikelas pada umumnya karena pada saat berinteraksi mereka menjadi tidak grogi, tidak merasa takut salah, dan menjadi lebih termotivasi.

Penelitian lainnya terkait kemauan berkomunikasi juga dilakukan oleh Mirsane dan Mona (2016) dimana dalam penelitian tersebut keduanya bertujuan untuk mencari tahu efek dari pengajaran strategi komunikasi terhadap kemauan siswa dalam berkomunikasi. Penelitian tersebut dilakukan pada siswa-siswa EFL (English Foreign Language). Untuk meningkatkan kemampuan berbahasa siswa, kemauan berkomunikasi (willingness to communicate) merupakan salah satu indikasi terbaik berhasilnya sebuah pembelajaran bahasa. Banyaknya pembelajar bahasa yang menghindari situasi berkomunikasi dan juga sempitnya kesempatan mereka untuk mengembangkan kemampuan berkomunikasi, memotivasi penulis untuk meneliti apakah pembelajaran strategi komunikasi berefek baik pada kemauan siswa untuk berkomunikasi. Untuk tujuan ini, 60 siswa dibagi menjadi dua grup, yaitu grup grup control dan grup experimen. Quesioner tentang kemauan berkomunikasi diberikan dua kali, sebelum dan sesudah perlakuan yang disebut pretest dan posttest. Hasil dari pretest dan posttest dari kedua grup dibandingkan menggunakan ANCOVA dan terbukti menunjukkan perbedaan signifikan antara keduanya, dimana grup eksperimen lebih baik dari grup control.

Table 4. Hasil Statistik Sampel Berpasangan

\begin{tabular}{|ll|r|r|r|r|}
\hline & Mean & N & Std. Deviation & $\begin{array}{c}\text { Std. Error } \\
\text { Mean }\end{array}$ \\
\hline \multirow{2}{*}{ Pair 1 } & CULTURAL2 & 4,7353 & 34 &, 14540 &, 02494 \\
& CULTURAL1 & 3,5176 & 34 &, 22084 &, 03787 \\
Pair 2 & CLASSROOM2 & 4,0042 & 34 &, 26896 &, 04613 \\
& CLASSROOM1 & 3,0000 & 34 &, 58954 &, 10111 \\
Pair 3 & SOCIALINDIVIDUAL2 & 4,0588 & 34 &, 16718 &, 02867 \\
& SOCIALINDIVIDUAL1 & 3,1588 & 34 &, 62042 &, 10640
\end{tabular}


Vol. 1 No. 4 Oktober 2021 e-ISSN : 2774-6283 | p-ISSN : 2775-0019

\begin{tabular}{|c|c|c|c|c|c|}
\hline & $\begin{array}{l}\text { SOCIALPSYCHOLOGI } \\
\text { CAL2 }\end{array}$ & 3,8382 & 34 & , 16722 & 02868 \\
\hline Pair 4 & $\begin{array}{l}\text { SOCIALPSYCHOLOGI } \\
\text { CAL1 }\end{array}$ & 2,8199 & 34 & 66869, & ,11468 \\
\hline
\end{tabular}

Table 5. Hasil T Sample Berpasangan

\begin{tabular}{|c|c|c|c|c|c|c|c|c|c|}
\hline & \multicolumn{5}{|c|}{ Paired Differences } & \multirow[t]{3}{*}{$\mathrm{t}$} & \multirow[t]{3}{*}{ df } & \multirow{3}{*}{$\begin{array}{l}\text { Sig. } \\
(2- \\
\text { tailed })\end{array}$} \\
\hline & & \multirow[t]{2}{*}{ Mean } & \multirow[t]{2}{*}{$\begin{array}{c}\text { Std. } \\
\text { Deviati } \\
\text { on }\end{array}$} & \multirow[t]{2}{*}{$\begin{array}{l}\text { Std. } \\
\text { Error } \\
\text { Mean }\end{array}$} & \multicolumn{2}{|c|}{$\begin{array}{c}95 \% \\
\text { Confidence } \\
\text { Interval of } \\
\text { the } \\
\text { Difference } \\
\end{array}$} & & & \\
\hline & & & & & $\begin{array}{c}\text { Lowe } \\
\mathrm{r}\end{array}$ & $\begin{array}{c}\text { Uppe } \\
\text { r }\end{array}$ & & & \\
\hline Pair 1 & $\begin{array}{l}\text { CULTURAL2 - } \\
\text { CULTURAL1 }\end{array}$ & $\begin{array}{r}1,2176 \\
5\end{array}$ & ,22760 & ,03903 & $\begin{array}{r}1,138 \\
23\end{array}$ & $\begin{array}{r}1,297 \\
06\end{array}$ & $\begin{array}{r}31,19 \\
6\end{array}$ & 33 &, 000 \\
\hline & CLASSROOM2 & 1,0042 &, 56543 & ,09697 &, 8069 & 1,201 & 10,35 & 33 & ,000 \\
\hline Pair 2 & - & & & & & & & & \\
\hline Pair 3 & $\begin{array}{l}\text { SOCIALINDIVI } \\
\text { DUAL2 - } \\
\text { SOCIALINDIVI } \\
\text { DUAL1 }\end{array}$ & ,90000 &, 62134 & , 10656 & $\begin{array}{r}, 6832 \\
1\end{array}$ & $\begin{array}{r}1,116 \\
79\end{array}$ & 8,446 & 33 & ,000 \\
\hline Pair 4 & $\begin{array}{l}\text { SOCIALPSYCH } \\
\text { OLOGICAL2 - } \\
\text { SOCIALPSYCH } \\
\text { OLOGICAL1 }\end{array}$ & $\begin{array}{r}1,0183 \\
8\end{array}$ & ,63076 & , 10817 & $\begin{array}{r}, 7983 \\
0\end{array}$ & $\begin{array}{r}1,238 \\
46\end{array}$ & 9,414 & 33 & ,000 \\
\hline
\end{tabular}

Sebagaimana tampak pada table 4 dan 5. aspek cultural (budaya) adalah aspek yang paling tinggi peningkatannya yaitu dari 3,5176 pada pretest menjadi 4,7353 pada posttest. Dari deskripsi diatas, dapat dilihat bahwa peningkatan aspek cultural $(1,21)$ adalah yang tertinggi dibandingkan dengan tiga aspek lainnya, yaitu 1,004 untuk konteks classroom, 0,90 untuk konteks sosial dan individual, serta 1,018 untuk konteks sosial dan psikologi. Untuk lebih jelasnya, table berikut merangkum hasil dari spss dari data diatas.

Table 6 Peningkatan aspek dari pretest ke post-test

\begin{tabular}{|c|l|c|c|c|}
\hline No & \multicolumn{1}{|c|}{ Aspects } & $\begin{array}{c}\text { Mean of } \\
\text { Pre-Test }\end{array}$ & $\begin{array}{c}\text { Mean of } \\
\text { Post-Test }\end{array}$ & Improvement \\
\hline 1 & Cultural Context & 3,5176 & 4,7353 & 1.2 \\
\hline 2 & Social and Individual Context & 3,1588 & 4,0588 & 0.9 \\
\hline 3 & Classroom Context & 3,0000 & 4,0042 & 1.0 \\
\hline 4 & $\begin{array}{l}\text { Social and Psychological } \\
\text { Context }\end{array}$ & 2,8199 & 3,8382 & 1.0 \\
\hline
\end{tabular}

Sebagaimana yang telah ditunjukkan oleh table 1 dan 2, peningkatan kemauan siswa untuk berkomunikasi dari pretest ke posttest adalah 1,2. Rata-rata nilai pretest adalah 3,07, dan rata-rata nilai posttest adalah 4,10. Dari sebanyak 25 pertanyaan pada kuesioner kemauan berkomunikasi, aspek budaya merupakan aspek yang mendapatkan prosentase tertinggi diantara aspek-aspek lainnya. Pada kuesioner tersebut, ada lima pertanyaan yang masuk kategori aspek budaya. Tabel berikut ini menunjukkan fakta tersebut lengkap dengan prosentase pilihan siswa pada pretest dan posttest. 
Tabel 7. Aspek budaya pada kuesioner kemauan berkomunikasi

\begin{tabular}{|c|c|c|c|c|}
\hline NO & Statements & $\begin{array}{c}\text { Mean of } \\
\text { Pretest }\end{array}$ & $\begin{array}{l}\text { Mean of } \\
\text { Posttest }\end{array}$ & Description \\
\hline 1 & $\begin{array}{l}\text { Memperkenalkan diri dalam Bahasa Inggris } \\
\text { dengan membawa catatan }\end{array}$ & 3,6 & 4,9 & Increase 1,3 \\
\hline 2 & $\begin{array}{l}\text { Memperkenalkan diri dalam Bahasa Inggris } \\
\text { tanpa membawa catatan. }\end{array}$ & 3,6 & 4,6 & Increase 1,0 \\
\hline 3 & Menyapa gurumu dalam Bahasa Inggris & 3,6 & 4,6 & Increase 1,0 \\
\hline 4 & Menyapa kawanmu dalam Bahasa Inggris. & 3,1 & 4,7 & Increase 1,6 \\
\hline 5 & $\begin{array}{l}\text { Mengucapkan terimakasih dalam Bahasa } \\
\text { Inggris saat kawanmu meminjamkan } \\
\text { penanya kepadamu. }\end{array}$ & 3,6 & 4,7 & Increase 1,1 \\
\hline
\end{tabular}

Pada aspek budaya, kemauan siswa untuk berkomunikasi tergantung pada orientasi budaya dimana satu diantaranya adalah ketakutan (rasa khawatir) akan kritikan, Pada poin sapaan, menyapa siswa satu sama lain dapat mereka lakukan dengan leluasa karena mereka tidak khawatir terhadap kritikan kawan. Mereka merasa bahwa mereka memiliki kemampuan yang sama dalam berkomunikasi Bahasa Inggris, sehingga merasa nyaman saat berbicara dengan teman. Sebagai hasilnya, kemauan untuk berkomunikasi mereka muncul. Hal ini dapat dlihat dari hasil pretest dan posttest sebagaimana yang tampak pada table 7 diatas. Pada table tersebut tertera bahwa dari kelima aspek budaya pada kemauan berkomunikasi, pernyataan nomor 4 ," Menyapa kawanmu dalam Bahasa Inggris" mendapatkan peningkatan yang paling signifikan (dari 3,1 ke 4,7).

Pada penelitian sebelumnya oleh Pattapong (2010), kemauan siswa untuk berkomunikasi tergantung pada orientasi budaya yang terklasifikasi sebagai kreng-jai, unity, fear of negative evaluation, dan teacher status (cara menghormati, kesatuan, rasa khawatir dikritik, dan status guru). Semua orientasi budaya tersebut merefleksikan dua buah konsep norma social masyarakat Thailand, yaitu : the desire to establish a network of relationships and to maintain the hierarchical system (keinginan untuk membangun hubungan dan melestarikan system senioritas). Kedua poin tersebut mengindikasi peran penting seorang teman bicara. Keempat klasifikasi diatas berbeda dengan penelitian ini karena penulis tidak menemukan aspek kreng-jay sebagai salah satu bagian dari kemauan untuk berkomunikasi. Akan tetapi, ada persamaan antara kedua penelitian tersebut dimana keduanya sama-sama memiliki aspek kesatuan, rasa khawatir dikritik, dan status guru sebagai factor-faktor yang berpengaruh terhadap kemauan siswa untuk berkomunikasi. Unity (kesatuan) berarti siswa memilih untuk berbicaraa atau tidak tergantung dari pasangannya. Lawan bicara dapat menentukan kemauan siswa untuk berkomunikasi karena mereka akan bersedia untuk berbicara pada saat mereka memiliki persamaan persepsi. Dilain sisi, pada saat siswa lain enggan berbicara itu artinya mereka memiliki kemauan berkomunikasi yang rendah dan sebagai hasilnya mereka pasif dalam interaksi kelas. Mereka sangat khawatir akan dikritik (negative evaluation). Menyapa guru dalam Bahasa Inggris (kuesioner No.3) dan menyapa teman dalam Bahasa Inggris (kuesioner No.4) merupakan dua refleksi dari kondisi ini.

\section{KESIMPULAN}

Dari data dan pembahasan, didapatkan kesimpulan bahwa: (1) berdasarkan hasil pretest dan posttest, maka hipotesa tes yang menyatakan bahwa implementasi pembelajaran 
menggunakan self video recording dapat menunjukkan perbedaan yang signifikan sebelum dan sesudah pelaksanaan pembelajaran selama $\mathrm{T}$-value $>\mathrm{T}$-table dengan tingkat signifikan dibawah 0,05 . Hipotesa Ho yang menyatakan bahwa tidak ada perbedaan yang signifikan sebelum dan sesudah perlakuan ditolak. Pada table tersebut tampak bahwa hasil nilai rata-rata posttest lebih tinggi daripada pretest (T-value 14,642 > T-tabel 2,0345). (2) Setelah membandingkan hasil pretest dan posttest, penulis mendapatkan fakta bahwasannya aspek kemauan berkomunikasi yang paling banyak dipengaruhi oleh implementasi pembelajaran multimedia melalui self video recording adalah aspek budaya, yaitu dari 3,5176 pada pretest menjadi 4,7353 pada posttest.

Dari kesimpulan di atas, dalam rangka meningkatkan kemampuan siswa untuk berkomunikasi maka implementasi self video recording dapat dijadikan satu alternatif yang mampu mewujudkannya. Dengan menggunakan self video recording, siswa menjadi kreatif dalam mencari variasi ungkapan yang mereka sesuaikan dengan tema yang mereka buat, menjadi mandiri karena memiliki keleluasaan dalam mencari ungjkapan pendukung, dan mereka mampu membangun Kerjasama yang baik dalam mencapai tujuan pembelajaran. Jadi disini students' centered learner bukan hanya merupakan wacana atau teori saja tapi telah mampu memberikan peluang kepada siswa menjadi makin inovatif, kreatif dan mandiri.

\section{DAFTAR PUSTAKA}

Chotipaktanasok. 2014. Enhancing Learners' Willingness to Communicate in English with Social Media. Dhurakij Pundit University.

Depdikas. (2016). Peraturan Menteri Pendidikan dan Kebudayaan Nomor 21 tahun 2016 Tentang Standar Isi Pendidikan Dasar dan Menengah. Jakarta : Depdiknas

Gardner, H. (1993). Multiple intelligences: The theory in practice. Basic Books

Gilakjani, Abas F. (2012). The Significant Role of Multimedia in Motivating EFL Learners' Interest in English Language Learning. Islamic Azad University, Lahijan, Iran

Goleman, D., Boyatzis, R. E. and McKee, A. (2002). Primal Leadership: Realizing the power of Emotional Intelligence. Harvard Business Press.

Kaptan, F., \& Korkmaz, H. (2000). Yapisalcilik (constructivism) kurami ve fen ogretimi: Cagdas Egitim Dergisi.

Mirsane, M. and Mona, K. (2016). The Effect of Teaching Communicative Strategy on EFL Learners' Willingness to Communicate. Islamic Azad University, Tehran, Iran

Pattapong, Kamlaitip. (2010). Willingness to communicate in a second language:A qualitative study of issues affecting Thai EFL learners from students' and teachers' points of view. Universiti of Sidney.

Pun, Min. (2013). The Use of Multimedia Technology in English Language Teaching: A Global Perspective. Prithvi Narayan Campus, Pokhara.

Rohani, Ahmad, A. M. (2004). Pengelolaan Pengajaran. Jakarta: PT Rineka Cipta.

Suharsimi, Arikunto, dkk (2006). Penelitian Tindakan Kelas. Jakarta: PT. Bumi Aksara.

Undang-Undang RI Nomor 20 Tahun 2003 Tentang Sistem Pendidikan Nasional. jakarta: Sinar Grafika. 